\title{
Closure threat at FDA laboratories
}

Drug testing

\section{facilities given}

\section{low priority}

Washington

The Food and Drug Administration (FDA) seems to be playing cat and mouse with the 500 members of the staff of its drug research laboratories in south-east and south-west Washington. Last month, as the Reagan Administration's budget problems became apparent, the FDA management raised the prospect that its three drug investigation laboratories might be shut. At the same time, all members of staff were advised that they should ensure that their career record forms (SF171) were complete by the end of October. This is a familiar preparation for dismissal. Although the Senate Appropriations Committee has now decided that the emergency cut of $\$ 40$ million in FDA's budget should be trimmed by $\$ 6$ million, members of staff have the impression that the laboratories' days are numbered.

FDA's response to last month's budgetary problems seems to have been unusually panicky. Senior officials of the administration were given 24 hours in which to define a package of economies amounting to 20 per cent of the budget. At a meeting on 16 October in the auditorium of FDA's Humphrey Building, more than 200 scientists were told that the investigation had shown that the Bureau of Drugs could dispense with its divisions of drug biology and of drug chemistry and the biopharmaceutics laboratory. It had already been decided that the national centre for antibiotic analysis, supported chiefly by fees from manufacturers with products to test, will be disbanded, largely on the grounds that its work could be carried out by private laboratories.

Anxiety about the future of the laboratories stems from the form of words used at the meeting on 16 October by Dr Richard Terselic, deputy director of the Bureau of Drugs. Terselic is reported to have told his audience that on several occasions in the past two or three years, studies of the consequences of large budget cuts had repeatedly shown the laboratories to be dispensable. Asked what would happen if the cut required of FDA was more like 5 per cent than 20 per cent, he is reported to have said that "if you have decided that $A$ is less important than B. . . there is a pressure in the system" that will make the less important activity vulnerable in future years.

A spokesman for FDA confirmed last week that the continuation of the work of the laboratories "has been identified as a low-priority area". He added that in the light of the action by the Senate Appropriations Committee, it was not now likely that the laboratories would be closed during the present financial year (which began on 1 October).

FDA's drug investigation laboratories occupy a central role in its regulation of new drugs. Their functions include the checking of manufacturers' claims for the safety of new materials and an assessment of the efficacy of materials proposed for medicinal use. Among the laboratories' claims on public attention is that they were the source of the first warnings of the dangers of thalidomide in the late 1950s.

Members of the laboratories claim that

\section{UK universities plan to fire staff}

British universities are still in a state of confusion over how to economize to meet the cuts in their grants. A major worry is still whether compensation to academics who lose their jobs will cost the universities more than savings in lost salaries. The answer will depend on how much extra money the government is willing to make available specifically for redundancy payments.

The Committee of Vice-Chancellors and Principals, which expects the first redundancies to be announced within a few weeks, now says that the matter is urgent. Last week it asked the University Grants Committee (UGC), which distributes government money among universities, to announce the terms under which it will compensate universities for redundancy payments.

The vice-chancellors' committee has provided the UGC with its own recommendations for the minimum compensation to which redundant academics should be entitled. Its scheme is intended to ensure fair treatment, especially for those academics whose contracts of employment do not give them security of tenure. Those with tenure, however, are likely to fight for higher compensation through the courts, making it still impossible to calculate the total redundancy bill. The best estimate remains that made in the summer of about $£ 250$ million.

The vice-chancellors' compensation scheme is based on that for civil servants. It is divided into three age categories - above 55 years, $50-55$ years and below 50 years. Under the scheme, academics aged 55 years and over would be entitled to compensation broadly in line with the existing premature retirement scheme which provides a lump sum and an early pension. For example, an academic aged 55 years with 30 years' service and a salary of $£ 15,410$ would receive $£ 23,115$ as a lump sum and $£ 7,705$ index-linked annual pension. Total cost to the university would be $£ 39,989$.

The vice-chancellors say that existing closure would compel the Bureau of Drugs to rely on post-marketing surveillance for the independent assessment of the efficacy of new drugs. It seems likely that such a departure from present practice would raise hackles in Congress. A letter-writing campaign by those concerned has been begun, while earlier this week it seemed likely that Congressman Albert Gore, chairman of the oversight subcommittee of the House of Representatives Committee on Science and Technology, would try to get to the bottom of FDA's intentions.

The outcome of a mandatory meeting of all the laboratory staff called for Tuesday this week is not yet apparent.

early retirement terms for academics aged 50-55 years are unfair. Accordingly, they recommend an additional lump sum payment to compensate for up to five years' loss of pension rights. Hence a redundant academic aged 50 with 25 years of service and an annual salary of $£ 15,410$ would receive a lump payment of $£ 21,566$ in addition to an index-linked pension of $£ 6,742$ a year and a further lump sum of $£ 20,226$. The total cost to the university would be $£ 72,150$.

Academics under 50 years of age would be entitled to a lump sum severance payment in addition to the normal lump sum and pension payable after retirement age. The total extra cost to the university would be only the lump sum payment. This would mean that an academic made redundant at age 40 years with 15 years of service and an annual salary of $£ 11,425$ would receive $£ 23,800$ on redundancy, a $£ 6,426$ lump sum and an annual pension of $£ 2,142$ after normal retirement age. The extra cost to the university would be $£ 23,800$.

The vice-chancellors' committee hopes that the UGC will adopt its scheme when deciding how to compensate universities for redundancy payments. But precisely how much money the UGC can make available remains uncertain. The $£ 20$ million already earmarked will almost certainly be inadequate, but much will depend on when the bills come in.

The vice-chancellors' scheme, however, is being given short shrift by the Association of University Teachers (AUT), the academics' trade union, which refuses to discuss the possibility of compulsory redundancy. The AUT believes that universities should make economies only through early retirement, frozen posts and non-payroll savings. It is adding its voice to requests that the government should spread the cuts over five instead of three years.

The AUT's threat to start legal proceedings at the first hint of compulsory redundancy, even before names are 
named, has already had an effect. Pressure from the local union branch at the University of Aston in Birmingham persuaded the university to postpone compulsory redundancies at least until the next academic year. Local pressure also persuaded the University of Keele to withdraw its notification of 300 impending redundancies to the Department of Employment. Other universities have also decided to delay job losses in an attempt to avoid being the first to be dragged through the courts. A handful are also apparently planning not to balance their books for several years. Their policy of living on borrowed money perhaps for three or four years is favoured by the AUT.

Judy Redfearn

\section{Science research council}

\section{Paying a price}

The capacity of the Science and Engineering Research Council to make research grants to British academics is likely to be impaired, in the year immediately ahead, because of the overspending by the council's Science Board, in the financial year that ended on 31 March. One of the ironies of this situation, described in the council's annual report for 1980-81, published last week, is that the chairman of the offending board, Professor John Kingman, has now succeeded Sir Geoffrey Allen as chairman of the council.

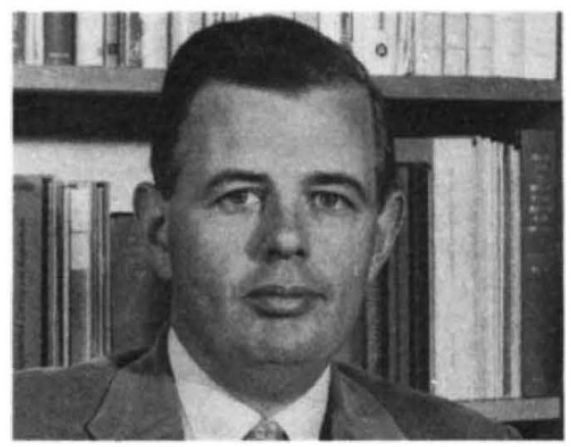

Kingman - poacher to gamekeeper?

According to the report, the council's allocation of funds to the science board will be reduced in the current year, while the board must repay to its master the outstanding amount of its over-spending.

The over-spending occurred, according to Professor Kingman, when the council decided to adopt a more bullish attitude to its spending to avoid falling into the trap of having money that it had not spent taken away by the government. In the event, it over-stepped the mark and received a sharp rap over the knuckles from the House of Commons Public Accounts Committee and a warning not to over-spend again.

Professor Kingman is confident that the council can do better this year. He expects spending to be within 0.15 per cent of the budget, the margin allowed by the Treasury, which he nevertheless complains is too narrow and would never be expected in industry.

Although the science board over-spent by only a small fraction of its annual budget ( $£ 64.4$ million in $1980-81$ ), the effect on its activities has been marked. During 1980-81, the announcement of some research grants to universities had to be delayed for lack of funds. The repayments this year and next will also not help the board meet its future commitments, about one-third of which are to research and teaching in universities.

According to the annual report, support for university research, a third of which is channelled through the science board, had to be cut somewhat during 1980-81. Matters this year are complicated by the cut in university income which is increasing pressure on the council's research grants.

But the report, for which Sir Geoffrey Allen is responsible, says that spending on research grants should soon be restored at least to the level of recent years. Nevertheless, it is unlikely that the council will be able to support all grant applications given its highest merit grading of alpha.

The council, in 1980-82, spent $£ 56.5$ million on research grants out of its total budget of $£ 207.8$ million. A few more grants were awarded than in the previous year but the increase was due almost entirely to an unusually large number of requests for continuing support in some areas. A total of 1,983 research grants, valued at $£ 74.5$ million, were recommended in 1980-81 compared with 2,412 awarded in 1979-80.

Judy Redfearn

\section{New man in}

Within a week of the resignation of the president and director-general of the French research agency, the Centre National de la Recherche Scientifique (CNRS) (Nature 5 November, p.3), a new director-general has been appointed: the long-time socialist party member M. Jean-Jacques Payan, a 46-year-old mathematician, and president of the University of Grenoble I.

The presidency of CNRS remains unfilled, although constitutionally the president has to help select the directorgeneral. However, the director-general bears the main management load, and so the filling of this post was considered the more urgent.

M. Payan's first task will be to reestablish confidence in the CNRS management, to represent CNRS in the national colloquium on science and technology (which takes place in January) and to consider the reorganization of CNRS - particularly taking into account the strongly expressed wish of the engineers, technicians and administrators of the many CNRS laboratories to play a more significant role in policy-making.

Robert Walgate
German energy policy

\section{The future unclear}

Count Otto Lambsdorff, the West German economics minister, was balanced on a precarious political tight-rope last week, when he announced the governing coalition's energy policy for the next decade. Judging by his description of the "third continuation of the energy programme"' (the second continuation was in 1977), he had little money, little energy and few plans. Or at least he had few plans he would admit to, for fear of rocking the coalition.

For example, to prepare the third continuation, Lambsdorff had asked several German economic institutes to make forecasts of energy needs and production. Usually a government will give guideline projections for the total economy in such circumstances; but Lambsdorff could not or would not provide them. And while the institutes clearly recommended a quadrupling of nuclear power generation by 1995 (from 3.7 per cent of primary energy to 17 per cent), Lambsdorff would only commit himself to the remark that "nuclear energy must provide an increasing percentage of baseload electricity".

Several factors lie behind this imprecision - strong local opposition within the Social Democratic Party (SDP), one of the coalition partners, to the expansion of nuclear power; the possible retirement of Chancellor Schmidt through ill-health before the 1984 general elections, complicated by the lack of an obvious successor; and the forthcoming fight in the local government elections next year, when SDP must present as united a front as it can.

Were it not for these political complications, the government would no doubt like to commit itself firmly to cheap nuclear power, which - behind the scenes - it sees as essential for maintaining the competitiveness of German industry. But if nuclear power is to be cheap, it must be plentiful, goes the calculation. A new German 1,300-MW pressurized water nuclear power station would" cost nearly twice as much in Germany as in France, a German manufacturer claimed recently. According to the company, this is largely because the French companies were "tooled up" for long production runs, and environmental regulations and delays are less extreme in France. At best, nuclear power might contribute 25 per cent of German electricity by the mid-1980s, compared with France's 70 per cent by 1990 , the company estimated.

Nevetheless, it is not good politics in SDP at present to be seen to be a strong supporter of nuclear power, in spite of the fact that there seems recently to have been a change of mood among the German public. Germany's strong dependence on oil and gas keeps domestic energy prices high, and the nuclear industry's claims that 